\title{
VIRUS (2013): EL CINE COMO UNA HERRAMIENTA EN LA DOCENCIA, CON APROXIMACIONES MÉDICAS Y MOLECULARES
}

\section{Virus (2013): cinema as a tool in teaching, with medical and molecular approaches}

Stefania CEVALLOS SOLÓRZANO ${ }^{1}$; Mikaela Alejandra CELI HERRERA²; Nathaly Maribel CALVA MORQUECHO ${ }^{2}$; Yuliana Elizabeth GUAYANAY CALVA ${ }^{2}$

${ }^{1}$ Departamento de Ciencias Biológicas, Universidad Técnica Particular de Loja, Loja (Ecuador). ${ }^{2}$ Área Biológica y Biomédica. Universidad Técnica Particular de Loja, Loja (Ecuador).

Correo electrónico: scevallos@utpl.edu.ec

Recibido: 2 de diciembre de 2020

Aceptado: 13 de enero de 2021

\section{Resumen}

El cine es un recurso formativo que se ha empleado frecuentemente para facilitar el aprendizaje en las ciencias de la salud. Se describe y analiza el contenido biomédico de la película Virus, orientada a presentar el contagio masivo por virus de la influenza A H5N1. El virus, al presentar mutaciones que favorecen el contagio entre animales y seres humanos, tiene el potencial para convertirse en pandemia. En el transcurso de la película se revelan falencias del gobierno de Corea del Sur ya que las acciones para enfrentar esta inminente pandemia no toman en cuenta los criterios médicos y científico, concurriendo en acciones de lesa humanidad. Una producción con una trama de ficción, terror y catástrofe donde el miedo y la paranoia contagian tanto como la propia enfermedad.

Palabras clave: estrategia educativa; ciencia-ficción; epidemia; ética. 


\title{
VIRUS (2013): EL CINE COMO UNA HERRAMIENTA EN LA DOCENCIA, CON APROXIMACIONES MÉDICAS Y MOLECULARES \\ STEFANIA CEVALLOS SOLÓRZANO; MIKAELA ALEJANDRA CELI HERRERA; NATHALY MARIBEL CALVA MORQUECHO; YULIANA ELIZABETH GUAYANAY CALVA
}

\begin{abstract}
Summary
Cinema is a training resource that has been used frequently to facilitate learning in the health sciences. The biomedical content of the film Virus is described and analyzed, aimed at presenting the massive contagion by influenza A H5N1 viruses. The virus by presenting mutations that favor contagion between animals and humans, has the potential to become a pandemic. During the film, shortcomings of the South Korean government are revealed since the actions to face this imminent pandemic do not take into account medical and scientific criteria, concurring in actions against humanity. A production with a plot of fiction, terror, and catastrophe where fear and paranoia are as contagious as the disease itself.
\end{abstract}

Keywords: educational strategy; science fiction; epidemic; ethic.

\section{Ficha Técnica}

Título: Virus (The Flux).

Título original: 감 기 (Gamgi).

País: Corea del Sur.

Año: 2013.

Director: Kim Sung-su.

Música: Kim Tae-seong.

Fotografía: Lee Mo-gae.

Montaje: Nam Na-yeong.

Guion: Lee Yeong-jong, Kim Sung-su.

Intérpretes: Soo Ae, Jang Hyuk, Park Min-ha, Yoo Hae-jin, Ma Dong-seok, Lee Hee-joon, Kim Ki-hyeon, Cha In-pyo, Lee Sang-yeob, Park Hyo-joo, Park Jung-min, Lester Avan Andrada, ...

Color: color.

Duración: 121 minutos.

Género: ciencia ficción, terror, cine catástrofe.

Sinópsis: El distrito surcoreano de Bundang-gu debe enfrentar una repentina proliferación del virus $H 5 N 1$, enfermedad que mata a sus víctimas tras 36 horas de infectar el organismo. El virus, altamente contagioso y transmitido por vía respiratoria, llega al distrito por un grupo de inmigrantes ilegales contagiados. En medio del caos, el bombero, Kang Ji-goo conocerá a Kim In-hae, una médica, con la que deberá enfrentar esta terrible y mortal amenaza.

Productora: iLoveCinema, iFilm Corp.

Enlace: https://www.imdb.com/title/ tt2351310/?ref_=fn_al_tt_1 Trailer

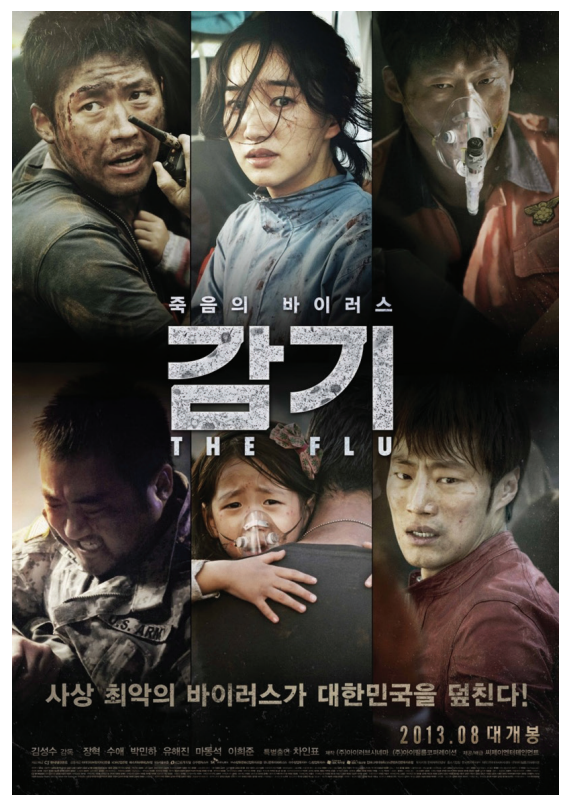




\section{VIRUS (2013): EL CINE COMO UNA HERRAMIENTA EN LA DOCENCIA, CON APROXIMACIONES MÉDICAS Y MOLECULARES}

STEFANIA CEVALLOS SOLÓRZANO; MIKAELA ALEJANDRA CELI HERRERA; NATHALY MARIBEL CALVA MORQUECHO; YULIANA ELIZABETH GUAYANAY CALVA

\section{La trama}

La película se desarrolla en la ciudad de Bundang-gu distrito de Seongnam, ciudad de Seúl (Corea del Sur), donde existe la amenaza de una potencial pandemia por el virus H5N1 que surge como una mutación del virus de la gripe aviar (H7N9). En la película se hace hincapié en lo sencillo que resulta la propagación del virus ya que, un individuo infectado es capaz de transmitir el patógeno por vía aérea: a través de partículas o gotas de agua (Foto 1 ).

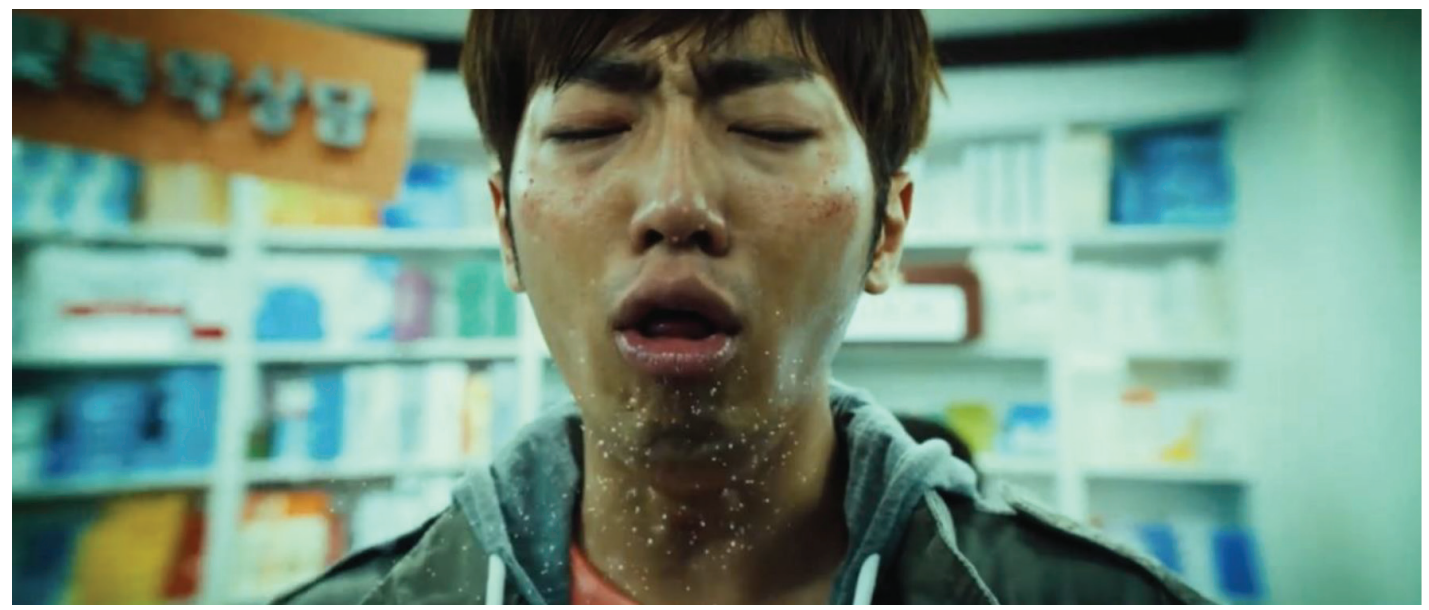

Foto 1: Contagio del virus por vía respiratoria.

En el servicio de emergencias, se registra el primer infectado, que presenta desde hace 24 horas: tos no productiva, alza térmica no cuantificada, malestar general, odinofagia, dificultad para respirar y erupciones cutáneas. Estas últimas en la región de la cara representan una de las características más determinantes para el diagnóstico (Foto 2).

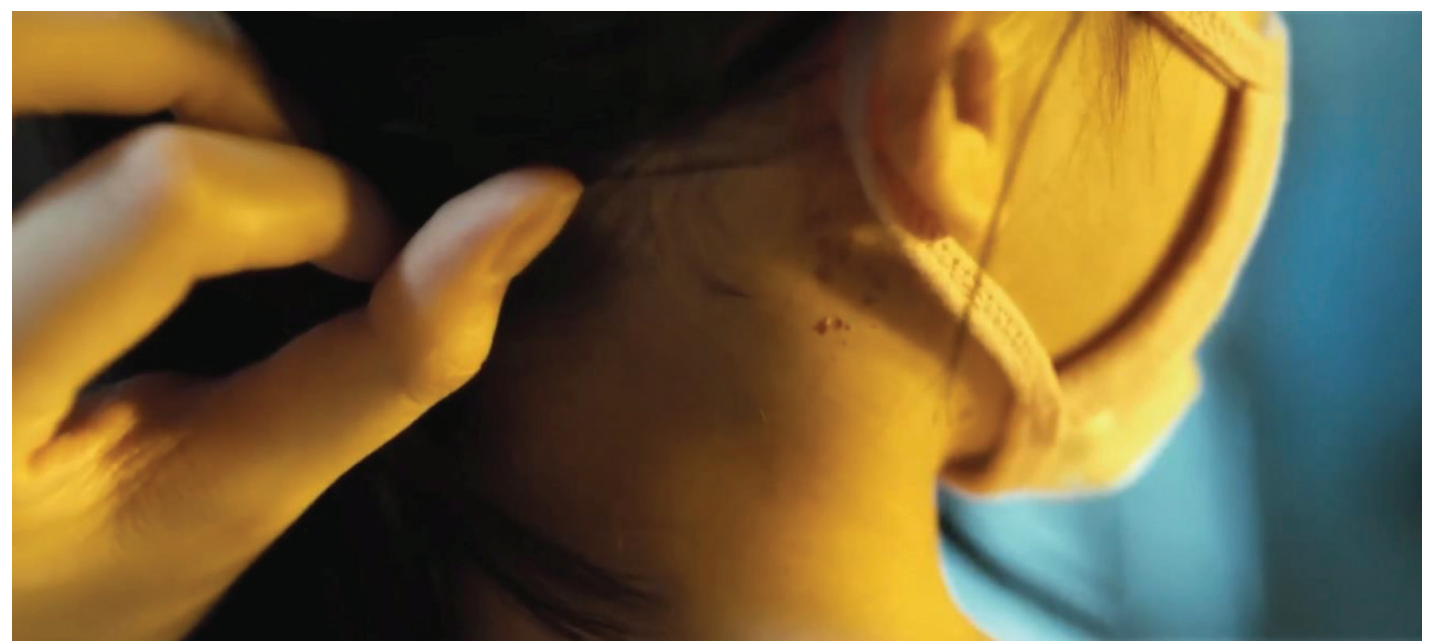

Foto 2: Sarpullido cutáneo es uno de los primeros signos de la enfermedad. 


\section{VIRUS (2013): EL CINE COMO UNA HERRAMIENTA EN LA DOCENCIA, CON APROXIMACIONES MÉDICAS Y MOLECULARES}

STEFANIA CEVALLOS SOLÓRZANO; MIKAELA ALEJANDRA CELI HERRERA; NATHALY MARIBEL CALVA MORQUECHO; YULIANA ELIZABETH GUAYANAY CALVA

Se sospecha de un síndrome de disfunantecedente de casos en China (Shangai, Zheción multiorgánica, gripe aviar H7N9, al existir jiang y Jiangsy) y Vietnam (Foto 3).

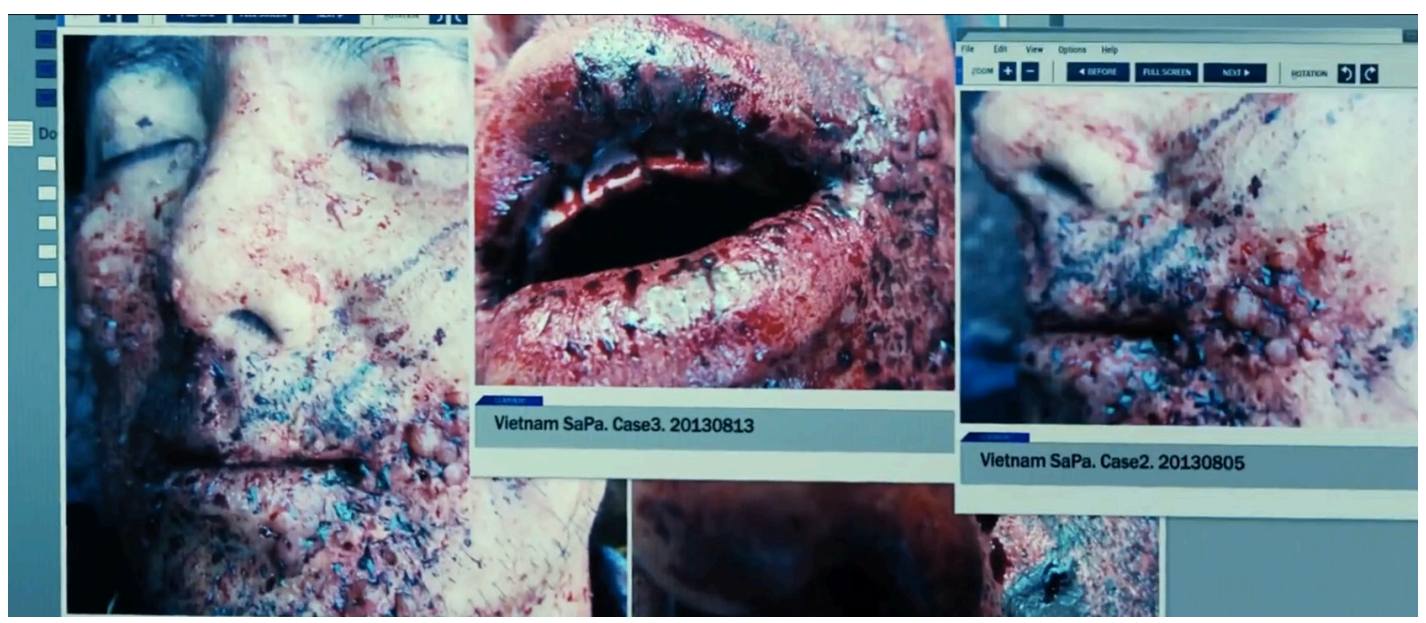

Foto 3: Contraste del cuadro clínico con los síntomas de la gripe aviar presentada en Vietnam.

Por el desconocimiento de la colectividad y la falta de decisiones de las autoridades, que minimizan esta situación y hacen caso omiso de la comunidad médica, esto resultará en un contagio masivo. Con el paso de las horas la mitad de la población de este distrito se ve afectada y el sistema hospitalario colapsa. El personal médico desconoce de un tratamiento adecuado y la propagación resulta incontrolable.

La situación empeoró cuando la población entra en cuarentena y son segmentados en zonas dentro de un campamento. Cada individuo se evalúa físicamente y se le realiza un hisopado orofaríngeo para una prueba usando PCR (polymerase chain reaction) (Foto 4).

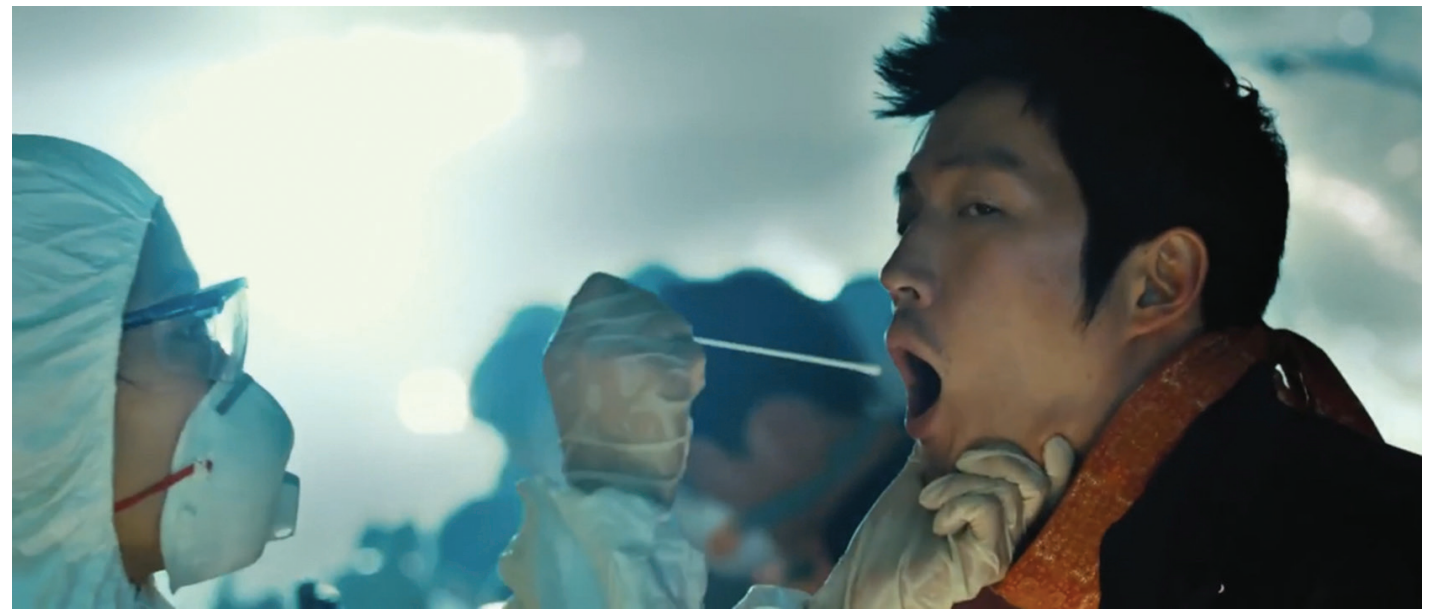

Foto 4. Toma de muestra para prueba PCR.

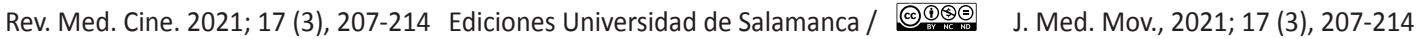
[ 210] 


\section{VIRUS (2013): EL CINE COMO UNA HERRAMIENTA EN LA DOCENCIA, CON APROXIMACIONES MÉDICAS Y MOLECULARES \\ STEFANIA CEVALLOS SOLÓRZANO; MIKAELA ALEJANDRA CELI HERRERA; NATHALY MARIBEL CALVA MORQUECHO; YULIANA ELIZABETH GUAYANAY CALVA}

Desafortunadamente, las personas infectadas no reciben ningún tratamiento y son inmanejables para el sistema de salud, por lo que el gobierno decide incinerarlos vivos con el fin de mitigar la propagación, afectando los derechos de la población. El colapso social se da cuando la población es consciente de los planes del gobierno, pero esto resulta en un aumento de la mortalidad.

Los médicos y científicos trabajan contra tiempo para obtener una vacuna con base en los anticuerpos de la única paciente recuperada (Foto 5).

\section{Descripción y análisis de elementos biomédicos}

Resulta importante abordar el virus de la influenza para comprender la trama. Existen cuatro tipos de virus de la influenza: A, B, C y D; cuyos hospedadores naturales son las aves acuáticas silvestres, en particular los patos, gansos, cisnes, gaviotas, aves costeras y golondrinas de mar $^{1}$.

Los virus de la influenza A se dividen en subtipos de acuerdo con dos proteínas de la superficie del virus: la hemaglutinina (HA) y la neuraminidasa (NA). En el caso del virus H5N1 tiene una proteína HA 5 y una proteína NA $1^{1}$.

Se ha identificado el virus de la influenza aviar tipo A como virus de influenza aviar altamente patógeno (HPAl) y virus de la influenza aviar de baja incidencia patógena (LPAI) según las características moleculares del virus y de la capacidad que tiene de causar enfermedades y muerte en pollos en condiciones de laboratorios, aunque ambos virus, de la LPAI y de la HPAI han provocado enfermedades graves en los humanos ${ }^{1}$.

La gripe se considera una enfermedad emergente, por la capacidad que tiene el virus de influenza $A$, de variar antigénicamente sus glicoproteínas externas y burlar así la inmunidad adquirida de las células infectadas. Esto obedece fundamentalmente a que su ácido nucleico es un ARN segmentado, el cual codifica por una ARN polimerasa que no tiene función de corregir los errores de lectura y, por lo tanto, se produce una alta tasa de mutaciones ${ }^{2}$.

El virus de la influenza aviar A (H5N1) altamente patógeno (HPAI) de origen asiático se da principalmente en aves y es sumamente contagioso. El virus H5N1 de la forma altamente

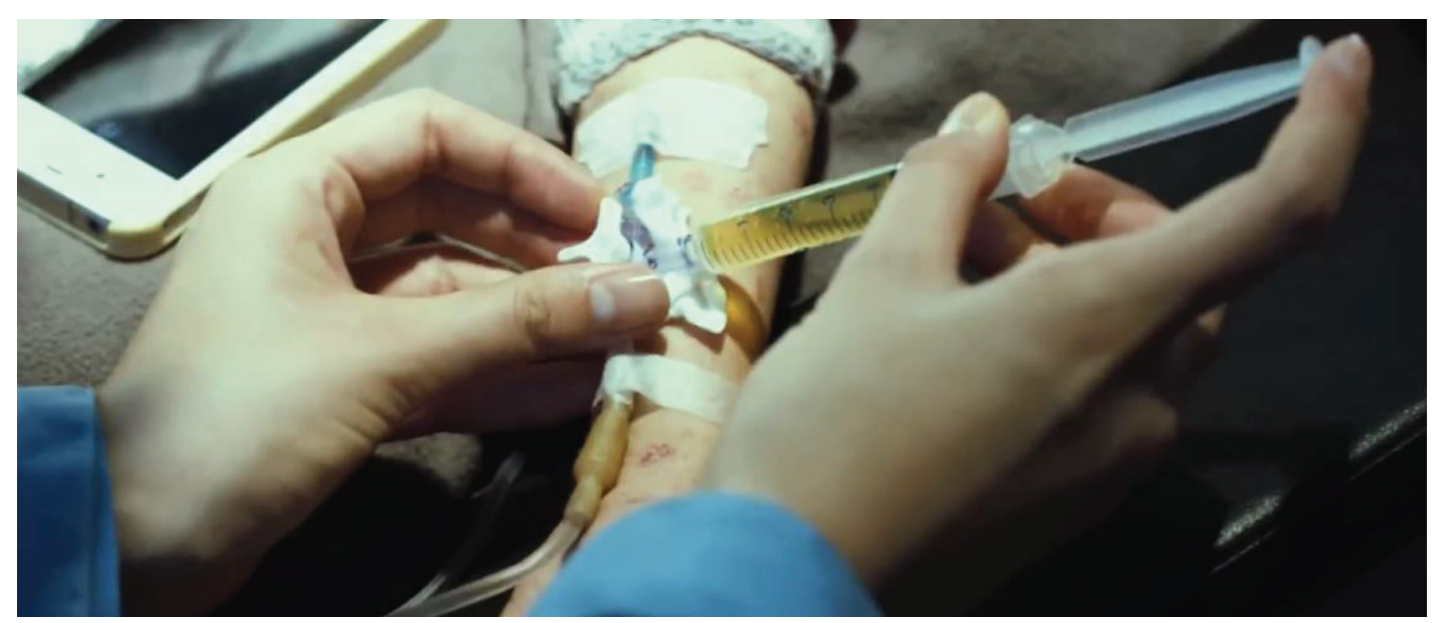

Foto 5: Transfusión de anticuerpos de un paciente que ha generado inmunidad frente al virus, hacia un paciente en estado crítico de la enfermedad. 


\section{VIRUS (2013): EL CINE COMO UNA HERRAMIENTA EN LA DOCENCIA, CON APROXIMACIONES MÉDICAS Y MOLECULARES \\ STEFANIA CEVALLOS SOLÓRZANO; MIKAELA ALEJANDRA CELI HERRERA; NATHALY MARIBEL CALVA MORQUECHO; YULIANA ELIZABETH GUAYANAY CALVA}

patógena de la influenza aviar de origen asiático, se detectó por primera vez en gansos en 1996 en China y se caracteriza por ser particularmente mortal entre las aves de corral. Seis países se consideran endémicos por el virus H5N1 de la forma altamente patógena de la influenza aviar de origen asiático detectado en las aves de corral (Bangladesh, China, Egipto, India, Indonesia y Vietnam). El primer registro de este virus en seres humanos se dio en 1997, consecuencia de un brote originado en aves de corral en Hong Kong $y$, desde entonces, se ha detectado en aves de corral y silvestres en más de 50 países de África, Asia, Europa y Oriente Medio. Sin embargo, se ha dado una reaparición generalizada en 2003 con reportes de infecciones esporádicas y poco comunes en seres humanos que comenzaron a informarse en Asia y más adelante en África, Europa y Oriente Medio ${ }^{3}$.

Los virus de la influenza cambian constantemente, en especial los virus de la influenza animal pueden mutar de tal manera que adquieren la capacidad de infectar fácilmente a las personas y diseminarse entre ellas hasta desencadenar una pandemia. Las infecciones en seres humanos por el virus de la influenza aviar, como el virus H5N1 de origen asiático, causan preocupación debido a su potencial pandémico ${ }^{3}$.

Las aves infectadas alojan virus de la influenza aviar en la saliva, las membranas mucosas y las heces. Cuando el virus está presente en el aire (gotas o polvo) o superficies, el virus puede entrar en las personas a través de los ojos, nariz, boca o por medio de la inhalación, causando la infección ${ }^{4}$.

En términos generales los virus reconocen un receptor específico en su célula hospedera que les permite hacer el primer contacto con la célula para iniciar la infección. En el caso de los virus de las aves, las hemaglutininas reconocen residuos de ácido siálico en unión con la galactosa en la membrana celular. Esta clase de receptores se encuentran particularmente en las células bronquiales no ciliadas, en las células alveolares y en la conjuntiva de los seres humanos. Las hemaglutininas de los virus humanos reconocen los residuos de ácido siálico con un enlace con la galactosa, el cual se puede encontrar en las células epiteliales de la mucosa nasal y paranasal, en la faringe, tráquea, bronquios y bronquiolos ${ }^{2}$.

La infección asintomática o leve por el virus H5N1 en humanos es posible, ya que los estudios de seroprevalencia así lo demuestran. En la infección sintomática, estos virus tienen la capacidad de afectar el sistema respiratorio superior e inferior, producir el síndrome de gastroenteritis aguda con diarrea, vómito y dolor abdominal, aunque también se puede presentar encefalitis. En los pacientes que surge neumonía, es posible que progresen a síndrome de insuficiencia respiratoria o síndrome de disfunción de múltiples órganos ${ }^{5}$.

Una vez que el virus entra a la célula, la síntesis de proteína celular se paraliza debido a la degradación de los mensajeros por la endonucleasa viral, produciendo pérdida de proteínas críticas que llevan a la muerte celular por necrosis. Se ha demostrado que la proteína no estructural (NS1) de los virus H5N1 tiene la capacidad de antagonizar el efecto antiviral del interferón y el factor de necrosis tumoral alfa (TNF- $\alpha$ ) producidos durante la respuesta inmune innata en contra de la infección ${ }^{2}$. Además, se ha demostrado in vitro que los virus H5N1 aislados desde humanos son mucho más potentes en inducir citoquinas por inflamación que los virus H1N1 y los H3N2, lo que acarrea a una cascada de citoquinas y muerte celular. Estos mecanismos explican por qué los pacientes presentan edema alveolar, hemorragia, exudación alveolar con macrófagos CD68 e infiltración intersticial con linfocitos $\mathrm{CD}^{2}$.

La mayoría de los casos de infecciones en seres humanos con el virus H5N1 HPAl de linaje asiático se han reportado entre niños y adultos menores de 40 años. La mortalidad más elevada 


\section{VIRUS (2013): EL CINE COMO UNA HERRAMIENTA EN LA DOCENCIA, CON APROXIMACIONES MÉDICAS Y MOLECULARES \\ STEFANIA CEVALLOS SOLÓRZANO; MIKAELA ALEJANDRA CELI HERRERA; NATHALY MARIBEL CALVA MORQUECHO; YULIANA ELIZABETH GUAYANAY CALVA}

se ha dado en personas entre 10 y 19 años de edad y en adultos jóvenes. En la mayoría de los casos infectados con el virus H5N1 HPAl de linaje asiático, los pacientes reciben atención médica en etapas avanzadas de la enfermedad y son hospitalizados con enfermedades respiratorias graves $^{6}$. Gran parte de los contagios de seres humanos con el virus H5N1 HPAl, de origen asiático, se da después de estar en contacto directo o cercano con aves de corral enfermas o muertas que hayan portado el virus. Otros factores de riesgo que influyen en el incremento de casos de infección de humanos con el virus H5N1 HPAI de origen asiático son las visitas a mercados de aves de corral vivas; contacto cercano, prolongado y sin protección con pacientes infectados y los períodos fríos ${ }^{5}$. Todavía se desconoce si dichas infecciones están relacionadas con factores genéticos o de otro tipo ${ }^{6}$.

Referente a las pruebas de diagnóstico en la película se indican pruebas bioquímicas (hemograma) y la prueba molecular PCR para la detección del virus H5N1. Específicamente, las pruebas son autorizados por la FDA (Food and Drug Administration), que incluyen pruebas rRT-PCR de diagnóstico (ensayos moleculares), pruebas de diagnóstico rápido de la influenza (RIDTs), ensayos de inmunofluorescencia y prueba serológica para anticuerpos específicos en muestras pareadas de suero. Para los análisis mencionados las muestras respiratorias se obtienen por hisopado nasofaríngeo, lavado o aspirado nasal, aspirado endotraqueal o lavado bronquioalveolar ${ }^{6}$. Adicionalmente, hay técnicas de seguimiento como: el ensayo de inhibición de la hemaglutinina $(\mathrm{IH})$, con el fin de caracterizar antigénicamente los virus de la influenza y el ensayo de microneutralización, que requiere el virus H5N1 vivo, con lo que se evalúa los anticuerpos específicos para virus H5N1 o $\mathrm{H} \mathrm{N}^{5}$. Finalmente, la caracterización genética mediante secuenciación de genoma viral por el método de Sanger y NGS (Next Generation Sequencing) que favorecen un diagnóstico molecular avanzada (AMD) ${ }^{7}$.

Referente al tratamiento que se da a los pacientes en la película, en un primer momento se administra oseltamivir, porque se presumía que estaban enfrentando un brote de gripe común. Sin embargo, posterior al descubrimiento de la nueva mutación del virus de la gripe aviar, se evidencia que no existe tratamiento que frene o mitigue la infección en las personas contagiadas. Todo el pueblo de Bundang-gu está esperanzado únicamente en el desarrollo de la vacuna basada en los anticuerpos contra el virus².

Las investigaciones desarrolladas desde el brote de H5N1 en Hong Kong, en 1997, han seguido la evolución de las cepas circulantes en Asia y se han escogido cepas que pueden servir como vacunas prepandémicas. Con las vacunas estacionales se ha demostrado que la eficacia de una vacuna depende del grado de similitud antigénica que tenga con la cepa circulante. Por lo tanto, la idea de una vacuna prepandémica es producir anticuerpos en los vacunados para que adquieran algún grado de protección².

El oseltamivir es el antiviral que se recomienda, ya que es absorbido y metabolizado, con capacidad de llegar al sistema gastrointestinal y al sistema nervioso, donde el virus H5N1 causa patología. Se ha demostrado resistencia al oseltamivir, pero en un porcentaje mucho menor que la amantadina. El uso de antivirales contra el virus influenza se utiliza como profilaxis, porque se ha demostrado que protege contra la infección en un $70 \%$ a un $80 \%$ de las personas, reduce las complicaciones, las hospitalizaciones y por lo tanto la mortalidad ${ }^{2}$.

\section{El cine como una herramienta de educación y aprendizaje en alumnos del área de salud}

El cine es un medio de comunicación y por tanto es necesario interpretar sus resultados para descubrir qué es lo que nos quiere comunicar. El cine puede actuar con un instrumento educativo, cuando se valora la capacidad que tiene una 


\section{VIRUS (2013): EL CINE COMO UNA HERRAMIENTA EN LA DOCENCIA, CON APROXIMACIONES MÉDICAS Y MOLECULARES \\ STEFANIA CEVALLOS SOLÓRZANO; MIKAELA ALEJANDRA CELI HERRERA; NATHALY MARIBEL CALVA MORQUECHO; YULIANA ELIZABETH GUAYANAY CALVA}

producción cinematográfica para formar e informar a través de la representación de lo que ocurre, ha ocurrido u ocurrirá en el mundo. Es importante ser conscientes que a través del cine las personas pueden aprender, desarrollar pensamiento crítico y capacidad de elección. Al ser el cine un reflejo de la sociedad al presentar situaciones típicas de la vida diaria, costumbres y tradiciones; tiene un potencial inmenso en el ámbito académico y puede resultar un pilar fundamental para la comprensión de temáticas difíciles, ya que el estudiante al visualizar una producción cinematográfica es capaz de asociar con lo que ocurre en su entorno y consecuentemente crear un sentido crítico, lo cual resulta esencial en su crecimiento profesional.

\section{Referencias}

1. Centros para el Control y la Prevención de Enfermedades, Centro Nacional de Vacunación y Enfermedades Respiratorias (NCIRD). Los virus de la influenza tipo A. CDC. 19 de abril de 2017. [consultado el 4 de julio de 2020].

2. Herrero-Uribe, L. El virus influenza y la gripe aviar. Influenza virus and avian flu. Acta Médica Costarricense. 2008;50(1):13-19.

3. Centros para el Control y la Prevención de Enfermedades, Centro Nacional de Vacunación y
Enfermedades Respiratorias (NCIRD). Virus de la influenza aviar $\mathrm{A}(\mathrm{H} 5 \mathrm{~N} 1)$ altamente patógena de origen asiático. CDC. 12 de diciembre de 2018. [consultado el 4 de julio de 2020].

4. Centros para el Control y la Prevención de Enfermedades, Centro Nacional de Vacunación y Enfermedades Respiratorias (NCIRD). Prevención y tratamiento contra el virus de la influenza aviar en humanos. CDC. 17 de abril de 2017. [consultado el 4 de julio de 2020].

5. Centros para el Control y la Prevención de Enfermedades, Centro Nacional de Vacunación y Enfermedades Respiratorias (NCIRD). Directrices provisionales sobre la recolección de muestras, el procesamiento y las pruebas en pacientes presuntamente infectados con los virus de la nueva influenza tipo A que causan enfermedades graves en humanos. CDC. 28 de mayo de 2014. [consultado el 8 de junio de 2020].

6. Centros para el Control y la Prevención de Enfermedades, Centro Nacional de Vacunación y Enfermedades Respiratorias (NCIRD). Influenza aviar A (H5N1) de origen asiático altamente patógena en personas. CDC. 18 de marzo de 2015. [consultado el 8 de junio de 2020].

7. Centros para el Control y la Prevención de Enfermedades, Centro Nacional de Vacunación y Enfermedades Respiratorias (NCIRD). Secuenciación de genomas y caracterización genética del virus de la influenza. CDC. 15 de octubre de 2019. [consultado el 4 de julio de 2020]. 